\title{
Extent of Socio Economic Change of Tribal through Rashtriya Krishi Vikas Yojna (RKVY) in Banswara District of Rajasthan, India
}

\author{
Shilpa Maheshwari, Rajeev Bairathi* \\ Department of Extension Education, RCA, Udaipur, India
}

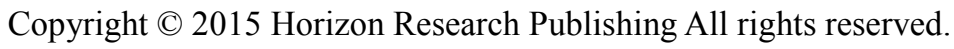

\begin{abstract}
Concerned by the slow growth in the agriculture and allied sectors, the National Development Council (NDC) resolved that a special additional central assistance scheme namely Rastriya Krishi Vikas Yojana (RKVY) be launched. The NDC resolved that agricultural development strategies must be reoriented to meet the needs of farmers and called upon the Central and State Governments to evolve a strategy to rejuvenate agriculture. The NDC reaffirmed its commitment to achieve 5.5 per cent annual growth in the agricultural sector during the $12^{\text {th }}$ plan. The present investigation was conducted in Banswara district of southern Rajasthan. Banswara and Ghatol tehsils were selected for the present study on the basis of maximum number of tribal population. The study reveals that the majority of tribal beneficiaries reported remarkable change with regard to social aspects like experience and confidence increased due to interaction with fellow member and training received. The change to a remarkable extent was found by majority of beneficiaries with regard to economic aspects such as overall family income increased, standard of feeding and clothing improved, material possessed including household increased.
\end{abstract}

Keywords Economic Change, Social Change, RKVY, Leadership

\section{Introduction}

India is a country of villages and agriculture is the main stay of the economy. According to the census of India, the total population of the country is about 1.21 billion marks on 2011. Out of total, poorer are 32.04 crores, this constitutes for 35.97 per cent poverty. At present $3 / 4^{\text {th }}$ of the Indian population is living in rural areas and two-third of this population directly or indirectly depends on agriculture sector for their livelihood. Moreover, 67 per cent of population is reported as under-employed and unemployed.
Concerned by the slow growth in the agriculture and allied sectors, the National Development Council (NDC), in its meeting held on $29^{\text {th }}$ May, 2007, resolved that a special additional central assistance scheme namely Rastriya Krishi Vikas Yojana (RKVY) be launched. The RKVY aims at achieving $5.5 \%$ annual growth in the agriculture sector during $12^{\text {th }}$ plan period by ensuring a holistic development of agriculture and allied sectors. The scheme is essentially a State Plan Scheme that seeks to provide the States and Territories of India with the autonomy to draw up plans for increased public investment in agriculture by incorporating information on local requirements, geographical/climatic conditions, available natural resources/ technology and cropping patterns in their districts so as to significantly increase the productivity of agriculture and its allied sectors and eventually maximize the returns of farmers in agriculture and its allied sectors.

The Twelfth Five-Year Plan looks through the past weaknesses in order to frame the new measures for the overall socio-economic development of the country. However, for a well-planned economy of any country, there should be a combined participation of the governmental agencies along with the general population of that nation. A combined effort of public, private, and all levels of government are essential for ensuring the growth of India's economy. The major thrust of the $12^{\text {th }}$ Five Year Plan is to build capacities and skills in sectors that have growing employment opportunities and are relevant to local socio-economic conditions. In its design, the plan should deal with important issues like income and poverty, education, health, women and children, infrastructure, financial empowerment, policy and legal exclusion and access to information and technology, raw materials and markets. It also emphasis to develop linkages with the organizations and programmes like the Rashtriya Krishi Vikas Yojna and other private sector organizations including vocational training institutions that can actually train and hire the tribal poor to meet their growing capacity needs. 


\section{Research Methodology}

The present investigation was conducted in Banswara district of Southern Rajasthan of India. Banswara and Ghatol tehsil were selected due to maximum number of tribal population in these tehsils. Ten villages were included for the investigation based on maximum number of tribal population. One hundred tribal respondents ( 50 beneficiaries and 50 non-beneficiaries) were selected from all selected villages ( 5 beneficiaries and 5 non-beneficiaries from each village) through random sampling technique. A schedule was constructed to measure the socio-economic change of RKVY tribal beneficiaries. The section contained quarries related to change in social and economic life of beneficiaries. The quarries were grouped under two sub-head viz. social change and economic change. Social change included total eleven items related to social life, where in, the improvement through RKVY was expected, while under sub-head economic change, total ten item were included which were related to areas were in improvement through RKVY was possible.

\section{Results and Discussion}

\section{Extent of Social Change}

The Table 1 intends to depict the data related to social change of tribal beneficiary respondents through RKVY. The data evidently shows that social prestige increased to a remarkable extent as it was reported by 36.00 per cent respondents. On the other hand, 50.00 per cent respondents reported increase to some extent in their social prestige after becoming RKVY beneficiaries. A small number of respondents i.e. 14.00 per cent reported no change in their social prestige because of their affiliation to RKVY.

Change to a remarkable extent was also reported to by 60.00 per cent respondents in their experience and confidence which increased due to their interaction with fellow member and training received under RKVY, whereas 24.00 per cent tribal beneficiaries reported the change to some extent in this aspect. Only 16.00 per cent respondents expressed that there was no change at all in their experience and confidence due to interaction with fellow member and training received.

Table 1 further shows that 24.00 per cent tribal beneficiaries observed a remarkable change as their children have joined non-formal (e.g. Anganwadi, Balwadi etc.) or formal institutes (e.g. school, college etc.), whereas 46.00 and 30.00 per cent tribal beneficiaries reported a moderate change and no change at all, respectively in this respect on account of RKVY. The programme of RKVY has made highly positive impact on the tribal beneficiaries with regard to increase in interest and aptitude towards work as it was reported by majority of tribal beneficiaries (38.00\%), whereas 32.00 per cent tribal beneficiaries viewed change to some extent in interest and aptitude towards work and 30.00 per cent of the tribal beneficiaries reported no change in this aspect. Regarding increase in leadership qualities, more or less equal number of tribal beneficiaries observed remarkable change and no change due to their affiliation to RKVY, while majority of respondents has observed increase to some extent in leadership qualities.

Table 1. Extent of social change of beneficiary respondents through RKVY

\begin{tabular}{|c|c|c|c|c|c|c|c|}
\hline \multirow{3}{*}{ S.No. } & \multirow{3}{*}{ Aspects } & \multicolumn{6}{|c|}{ Extent of social change } \\
\hline & & \multicolumn{2}{|c|}{ Remarkable extent } & \multicolumn{2}{|c|}{ Some extent } & \multicolumn{2}{|c|}{ Change not at all } \\
\hline & & $f$ & $\%$ & $\mathrm{f}$ & $\%$ & $\mathrm{f}$ & $\%$ \\
\hline 1. & Social prestige increased & 18 & 36.00 & 25 & 50.00 & 7 & 14.00 \\
\hline 2. & $\begin{array}{l}\text { Experience and confidence increased due to } \\
\text { interaction with fellow members and training } \\
\text { received }\end{array}$ & 30 & 60.00 & 12 & 24.00 & 8 & 16.00 \\
\hline 3. & $\begin{array}{c}\text { Children have joined non-formal (e.g. Anganwadi, } \\
\text { Balwadi etc.) or formal institute (e.g., school, } \\
\text { college etc.) }\end{array}$ & 12 & 24.00 & 23 & 46.00 & 15 & 30.00 \\
\hline 4. & Interest and aptitude has increase toward work & 16 & 32.00 & 19 & 38.00 & 15 & 30.00 \\
\hline 5. & Leadership qualities increased & 13 & 26.00 & 27 & 54.00 & 10 & 20.00 \\
\hline 6. & Participation in socio-cultural activities increased & 3 & 6.00 & 35 & 70.00 & 12 & 24.00 \\
\hline 7. & Health and hygienic, living environment increased & 0 & 0.00 & 36 & 72.00 & 18 & 36.00 \\
\hline 8. & $\begin{array}{c}\text { Membership in formal and informal organization } \\
\text { increased }\end{array}$ & 7 & 14.00 & 32 & 64.00 & 11 & 22.00 \\
\hline 9. & Illegal activities restricted & 5 & 10.00 & 26 & 52.00 & 19 & 38.00 \\
\hline 10 & $\begin{array}{c}\text { Transportation and communication facilities } \\
\text { increased }\end{array}$ & 9 & 18.00 & 27 & 54.00 & 14 & 28.00 \\
\hline 11. & $\begin{array}{l}\text { Knowledge and awareness about other welfare } \\
\text { programme increased }\end{array}$ & 13 & 26.00 & 25 & 50.00 & 12 & 24.00 \\
\hline
\end{tabular}

$\mathrm{f}=$ frequency, $\%=$ percentage

$\mathbf{n}=\mathbf{5 0}$ 
Similarly, participation in socio-culture activities increased to some extent as reported by majority of respondents $(70.00 \%)$ after becoming RKVY beneficiary, whereas only 6.00 per cent beneficiaries reported this change remarkable. About 24.00 per cent respondents have observed no change in participation in socio-cultural activities.

When we further look at the Table 1, it is found none of tribal beneficiaries observed a remarkable change with respect to health and hygienic living environment after becoming RKVY beneficiaries, while majority of respondents i.e. 72.00 per cent reported the moderate change in health and hygienic environment. About 36.00 per cent tribal beneficiaries expressed that there was no change in their health and hygienic environment because of their association with RKVY.

Regarding increase in membership of formal and informal organizations, it was found that 64.00 per cent tribal beneficiaries were enrolled in additional formal or informal organization after becoming RKVY beneficiaries, whereas 22.00 per cent respondents were not enrolled in any formal or informal organization and only 14.00 per cent respondents reported a remarkable change in getting membership of formal or informal organization. Improvement to some extent regarding illegal activities restricted, that might be in practice earlier, was reported by 52.00 per cent tribal beneficiaries respondents, whereas 38.00 per cent tribal beneficiaries reported no change in restriction of illegal activities after becoming RKVY beneficiary. Only 10.00 per cent tribal beneficiaries observed remarkable restriction in illegal activities after becoming RKVY beneficiaries.

Further analysis of Table 1 shows that 54.00 per cent tribal beneficiaries reported some change in increase of transport and communication facilities after becoming RKVY beneficiaries, whereas 28.00 per cent respondents reported no change in transport and communication facilities. About 18.00 per cent respondents viewed remarkable change in transport and communication facilities after becoming RKVY beneficiaries. Likewise, 50.00 per cent beneficiaries reported that knowledge and awareness about other welfare programmes has increased to some extent, whereas 26.00 per cent and 24.00 per cent tribal beneficiaries observed remarkable change and no change in this aspect, respectively after becoming RKVY beneficiaries.

To sum up of result regarding social change of RKVY beneficiaries, it can be concluded that majority of beneficiaries reported change to some extent in aspects namely "children have joined formal (e.g. anganwadi, balwadi etc.) and informal institute (e.g. school, college etc.'), 'interest and aptitude increased toward work', 'leadership qualities increased', 'participation in socio-cultural activities increased', 'health and hygienic living environment improved', 'membership in formal and informal organization increased', 'illegal activities restricted', 'transport and communication facilities increased' and 'knowledge and awareness about other welfare programme increased'. RKVY had been able to improve the social aspects to remarkable extent like experience and confidence increased due to interaction with fellow member and training received.

\section{Extent of economic change}

The data incorporated in Table 2 clearly shows that overall family income of majority of respondents $(64.00 \%)$ has increased to remarkable extent, whereas a little lesser per cent $(30.00 \%)$ of respondents reported an increase to some extent in their overall family income. Only 6.00 per cent beneficiaries reported no change in their family income after becoming RKVY beneficiary. Regarding improvement in standard of feeding and clothing after RKVY benefits, 22.00 per cent beneficiaries reported no improvement whereas 34.00 per cent respondents expressed that the standard of feeding and clothing has improved to some extent. The majority of respondents i.e. 44.00 per cent has observed that their standard of feeding and clothing has improved to a remarkable extent after their becoming beneficiaries of RKVY.

Table 2. Extent of economic change of beneficiary respondents through RKVY

\begin{tabular}{|c|c|c|c|c|c|c|c|}
\hline \multirow{2}{*}{ S.No. } & \multirow{2}{*}{ Aspects } & \multicolumn{5}{|c|}{ Extent of social change } \\
\cline { 3 - 8 } & & & \multicolumn{2}{|c|}{ Remarkable extent } & \multicolumn{2}{c|}{ Some extent } & \multicolumn{2}{c|}{ Change not at all } \\
\cline { 3 - 8 } & & $\mathrm{f}$ & $\%$ & $\mathrm{f}$ & $\%$ & $\mathrm{f}$ & $\%$ \\
\hline 1. & Overall family income has increased & 32 & 64.00 & 15 & 30.00 & 3 & 9.00 \\
\hline 2. & Standard of feeding and clothing improved & 22 & 44.00 & 17 & 34.00 & 11 & 22.00 \\
\hline 3. & Family saving improved & 18 & 36.00 & 30 & 60.00 & 2 & 4.00 \\
\hline 4. & Overall Standard of living improved & 14 & 28.00 & 21 & 42.00 & 15 & 30.00 \\
\hline 5. & Material possession including households increased & 29 & 58.00 & 11 & 22.00 & 10 & 20.00 \\
\hline 6. & Residential facilities improved & 10 & 20.00 & 37 & 74.00 & 3 & 6.00 \\
\hline 7. & Loan repaying capacity improved & 7 & 14.00 & 28 & 56.00 & 15 & 30.00 \\
\hline 8. & Get off from worries of every day employment & 17 & 34.00 & 28 & 56.00 & 5 & 10.00 \\
\hline 9. & Purchasing power increased & 13 & 26.00 & 25 & 50.00 & 12 & 24.00 \\
\hline 10. & New household assets developed & 2 & 4.00 & 30 & 60.00 & 18 & 36.00 \\
\hline
\end{tabular}

$\mathrm{f}=$ frequency, $\%=$ percentage 
A majority of respondents $(60.00 \%)$ reported that their family savings have improved to some extent after their association with RKVY, whereas 36.00 per cent reported a remarkable change in improving the family savings and only 4.00 per cent tribal beneficiaries reported no change in family savings after becoming RKVY beneficiaries.

Likewise, improvement in the overall standard of living to remarkable extent was viewed by 28.00 per cent tribal beneficiaries, whereas improvement to some extent in overall standard of living was reported by majority of respondent $(42.00 \%)$ and 30.00 per cent tribal beneficiaries observed no change in overall standard of living after becoming RKVY beneficiaries. Further analysis of table shows that 58.00 per cent beneficiaries reported that material possession including households increased to remarkable extent, whereas 22.00 per cent tribal beneficiaries reported that material possession including households increased to some extent after their participation in RKVY. No change in material possession including households was reported by only 20.00 per cent RKVY beneficiaries. Regarding improvement in residential facilities, majority of tribal beneficiaries $(74.00 \%)$ reported moderate change, whereas 20.00 per cent beneficiaries reported remarkable change in improvement of their residential facilities after their association with RKVY. Only 6.00 per cent tribal beneficiaries reported no change in residential facilities after becoming RKVY beneficiaries.

Out of 50 respondents, $7(14.00 \%)$ respondents expressed that loan repaying capacity has increased to a remarkable extent, while 28 respondents $(56.00 \%)$ observed the increase to some extent and $15(30.00 \%)$ respondents reported no change in case of loan repaying capacity.

The data incorporated in the Table 2 apparently shows that the majority of beneficiaries $(56.00 \%)$ reported that their worries to get every day employment has reduced to some extent, whereas 34.00 per cent tribal beneficiaries reported a change to remarkable extent on this aspect and only 10.00 per cent respondent reported no change at all in getting off from worries of every day employment after their affiliation with RKVY. Likewise, improvement in the purchasing power increased to remarkable extent as viewed by 26.00 per cent tribal beneficiaries, whereas improvement to some extent about this aspect was reported by majority of respondents $(50.00 \%)$ and 24.00 per cent tribal beneficiaries reported no change in improvement of purchasing power. Regarding new household assets developed, it was found that the majority of tribal beneficiaries $(60.00 \%)$ apparently showed improvement to some extent and only 4.00 per cent respondents showed change of remarkable extent in positive direction toward development of new household assets. About 36.00 per cent tribal beneficiaries reported no change in their household development after becoming RKVY beneficiaries.

From the above results regarding economic change in RKVY beneficiaries, it can be concluded that change to a remarkable extent was reported by majority of respondents in the aspect like overall family income increased, standard of feeding and clothing improved, material possessed including household increased in the study area. Regarding economic aspects namely family savings, overall standard of living, residential facilities, loan repaying capacity, get off worries of everyday employment, purchasing power, new household, the majority of tribal beneficiaries reported a moderate change. Hence, it may be concluded that improvement in most of economic aspects of life of RKVY beneficiaries were highly encouraging. Further inference can be drawn that impact of RKVY in economic change of its tribal beneficiaries was positive and significant in the study area.

\section{Conclusions}

To sum up of result regarding social change of RKVY beneficiaries, it can be concluded that majority of beneficiaries reported change to some extent in aspects namely 'children have joined formal (e.g. anganwadi, balwadi etc.) and informal institute (e.g. school, college etc.'), 'interest and aptitude increased toward work', 'leadership qualities increased', 'participation in socio-cultural activities increased', 'health and hygienic living environment improved', 'membership in formal and informal organization increased', 'illegal activities restricted', 'transport and communication facilities increased' and 'knowledge and awareness about other welfare programme increased'. RKVY had been able to improve the social aspects to remarkable extent like experience and confidence increased due to interaction with fellow member and training received.

From the results regarding economic change in RKVY beneficiaries, it can be concluded that change to a remarkable extent was reported by majority of respondents in the aspects like 'overall family income has increased', 'standard of feeding and clothing improved', 'material possessed including household increased'. Regarding economic aspects namely 'family saving', 'overall standard of living', 'residential facilities', 'loan repaying capacity', 'get off worries of everyday employment', 'purchasing power', 'developed new household', change to some extent was reported by majority of tribal beneficiaries.

\section{REFERENCES}

[1] Singh, A., Gautam, U.S. and Singh, S.R.K. 2012. Socio-economic empowerment of farm women in Madhya Pradesh through suitable technological interventions: A Krishi Vigyan Kendra (KVK) approach. Indian Journal of Extension Education, 48 (1 \& 2) 74-77.

[2] Singh, A., Sharma, S.K. and Henry, C. 2010. Impact of women self help group in changing socio-economic status of rural families in Bikaner District of Rajasthan. Rajasthan Journal of Extension. Education, 17 \& 18: 112-114. 
[3] Yadav, M., Singh, K.C., Chouhan, A.S. and Singh, C.J. 2013. socio-economic changes among the farmers in relation to
Watershed Development Programme. Indian Research Journal of Extension Education, 13 (1): 42-44 